\title{
PKM PEMBERDAYAAN KELOMPOK PENGGERAK PARIWISATA MELALUI PELATIHAN BAHASA INGGRIS DI KAWASAN WISATA PANTAI LIMAN, PULAU SEMAU- KABUPATEN KUPANG, NUSA TENGGARA TIMUR
}

\author{
Ifoni Ludji ${ }^{1}$, Erny S. N. Hambandima ${ }^{2}$ \\ ${ }^{1,2)}$ Pendidikan Bahasa Inggris, Fakultas Keguruan dan Ilmu Pendidikan, \\ Universitas Kristen Artha Wacana Kupang \\ e-mail: ifoniludji@gmail.com ${ }^{1}$, ernyhambandima@gmail.com ${ }^{2}$
}

\begin{abstract}
Pantai Liman terletak di Selatan Pulau Semau yang memiliki potensi yang besar untuk menjadi sebuah kawasan wisata. Namun untuk mengembangkan keberhasilan sebagai sebuah kawasan wisata harus didukung oleh berbagai faktor dan komponen pendukung. Salah satu komponen pendukung adalah keterlibatan masyarakat dalam mengembangkan desa wisata. Sedangkan keterbatasan kapasitas pengetahuan dan juga ketrampilan yang dimiliki oleh masyarakat dalam penguasaan bahasa asing khususnya bahasa Inggris menghambat perkembangan kepariwisataan di daerah tersebut. Oleh karena itu, perlu dilakukan metode pelatihan bahasa Inggris. Adapun metode yang digunakan dalam pelatihan ini adalah ceramah, demonstrasi, diskusi, percakapan, drilling, dan bermain peran. Hasil yang dicapai dari kegiatan ini adalah hampir sebagian besar peserta yang mengikuti kegiatan ini mengalami peningkatan dalam berbahasa Inggris dimana para peserta sudah bisa berbicara, memberikan respon dan melakukan percakapan singkat diantara mereka dalam bahasa Inggris sederhana dan mereka tidak lagi takut untuk berbicara dalam bahasa Inggris, dan bisa mengucapkan kata-kata dengan pengucapan dan intonasi yang baik terkait topik-topik dalam materi.
\end{abstract}

Kata Kunci: Pelatihan Bahasa Inggris, Penggerak Pariwisata, Kawasan wisata

\begin{abstract}
Liman beach is located in the south Semau district which has the great potential to become as one of the tourism sites. However, to develop success as a tourism site it should be supported by numerous factors and supporting components. One of the components is the involvement of the communities in developing the tourism village. While the limited capacity of the knowledge and skills that the communities have in the mastery of the foreign language especially the English Language could ruin the tourism development in that area. Therefore, it is necessary to conduct the training method in the English language. The methods used in this training were lecture, demonstration, discussion, conversation, drilling, and role play. The result achieved from this activity are: most of the participants are improving in their English where the partcipants were able to speak, respond and do a short conversation among them in simple English and They were not afraid to speak English. Moreover, they could pronounce words correctly and having a good pronounciation related to the topics in the material.
\end{abstract}

Keywords: English Language Training, tourism Practitioners ,Tourism site.

\section{PENDAHULUAN}

Sektor kepariwisataan merupakan salah satu sektor industri yang sangat memberikan kontribusi pertumbuhan perekonomian yang sangat besar bagi negara. Hal ini nampak jelas oleh karena salah satu sumber devisa negara yang terbesar diperoleh melalui kegiatan kepariwisataan. Selain itu, kontibusi besar juga diberikan dengan daya serap lapangan kerja yang besar yang diberikan melalui kegiatan kepariwisataan.

Pantai Liman di Pulau Semau, Kabupaten Kupang Nusa Tenggara Timur memiliki panorama alam yang indah dengan hamparan pasir putih yang luas dan keindahan alam sekitar yang sangat mempesona, nyaman, tenang dan jauh dari keramaian sehingga sangat cocok bagi pengunjung yang ingin menghabiskan akhir pekan atau waktu liburan panjangnya. Hal ini tentunya 
akan menjadi incaran bagi para wisatawan baik dalam negeri maupun mancanegara untuk menjadi tujuan tempat wisata.

Destinasi wisata pantai Liman dengan potensi wisata yang sangat menarik akan mampu mendorong pertumbuhan perekonomian dikawasan wilayah tersebut dan juga Pulau Semau. Potensi wisata dari Pantai Liman ini menjadi lebih kuat dengan adanya penetapan kawasan ini sebagai salah satu destinasi wisata unggulan yang mendapat nominator Anugerah Pesona Indonesia (API) 2020.

Dengan penetapan nominasi Anugerah Pesona Indonesia dan kemajuan yang berkembang pada kawasan pantai Liman ini, keterlibatan masyarakat khususnya masyarakat yang berada pada kawasan ini perlu dipersiapkan sedini mungkin untuk menyambut peningkatan kunjungan wisatawan baik dari dalam maupun dari luar negeri dengan baik sehingga semua wisatawan yang datang berkunjung ke tempat ini merasakan kepuasan yang baik dan ingin terus untuk kembali berkunjung ke tempat ini. Oleh karena itu, persiapan dan pengembangan sumber daya manusia (SDM) menjadi sangat penting dan diperlukan untuk menjalankan kegiatan kepariwisataan yang berlangsung. Raharjana (2010) menyatakan bahwa pelibatan masyarakat dalam pengembangan desa wisata seharusnya dimulai sejak proses perencanaan.

Berdasarkan pantauan di lapangan tak dapat disangkal bahwa masyarakat sekitar kawasan wisata ini khususnya yang masuk sebagai kelompok penggerak pariwisata yaitu anak-anak dan orang-orang dewasa memiliki kelemahan berkomunikasi dalam bahasa Inggris untuk diterapkan dalam komunikasi sehari-hari dan juga ketidak ketersediaannya jasa pelayanan pelatihan bahasa Inggris yang ada di desa ini khususnya pada kawasan sekitar pantai liman menjadi kendala yang besar dalam peningkatan kemajuan aktifitas kepariwisataan sehingga pelayanan pelatihan bahasa Inggris menjadi sangat perlu guna membantu mengatasi masalah yang ada.

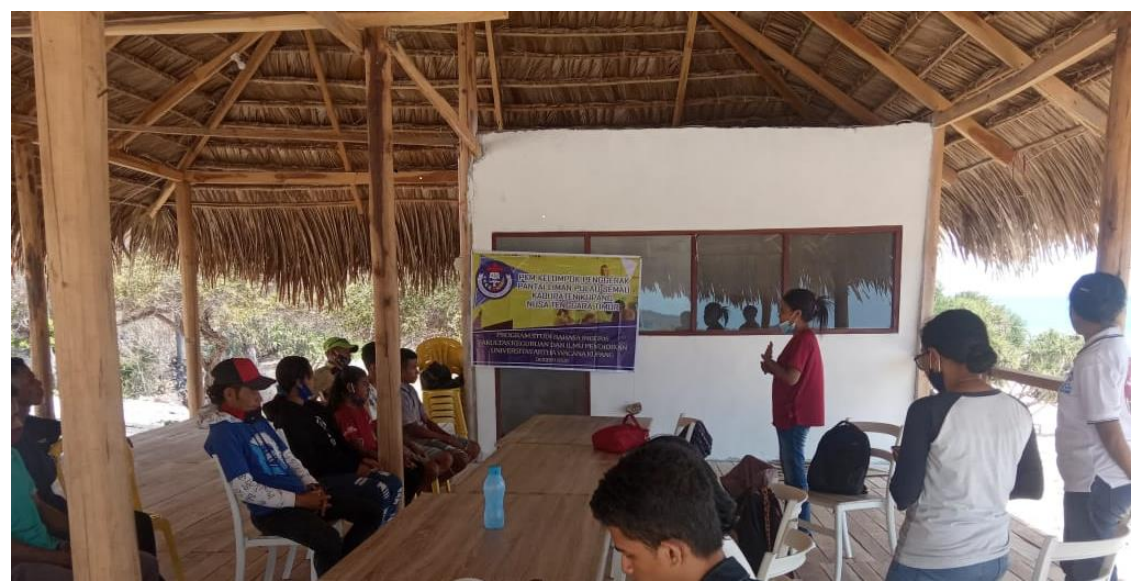

Gambar 1. Pertemuan dengan Kepala Desa dan para peserta kelompok penggerak wisata untuk membahas rencana pelaksanaan kegiatan Program Pengabdian kepada Masyarakat.

\section{METODE}

Dalam mengatasi masalah yang telah dipaparkan sebelumnya, maka pemberian pelatihan bahasa Inggris menjadi hal yang sangat penting dan diperlukan untuk dilakukan bagi para kelompok penggerak pariwisata di pantai Liman, desa Liman. Melalui kegiatan pelatihan ini diharapkan dapat memberikan pengetahuan tentang pentingnya memiliki kemampuan berbahasa Inggris guna membantu mereka untuk dapat berkomunikasi dengan wisatawan asing yang datang berkunjung ke kawasan wisata ini sehingga lewat komunikasi dan interaksi yang terjadi mereka akan mampu menawarkan atau menjual produk usaha yang ada. Sebagai hasilnya adalah peningkatan perekonomian dari masyarakat dapat meningkat sehingga kesejahteraan masyarakat menjadi lebih baik.

Dalam kegiatan pelatihan ini, cakupan materi yang diberikan lebih kepada bahasa Inggris praktis untuk komunikasi sehari-hari dan tentang kepariwisataan yang meliputi ketrampilan mendengar dan juga berbicara. Dengan kedua ketrampilan ini akan sangat menolong mereka unrtuk bisa menyimak dan memahami dengan baik pesan yang disampaikan dan mampu untuk merespon atau menyampaikan pesan kepada orang lain yang menjadi target dalam komunikasi. 
Pelaksanaan kegiatan dilakukan melalui beberapa metode yaitu; ceramah, diskusi, demonstrasi, dan juga praktek berbicara lewat percakapan sederhana dan juga bermain peran yang keseluruhan aktifitas ini tentunya melibatkan semua peserta pelatihan bersama dengan tim pengabdi dan mahasiswa. Richard (2001), menyebutkan bahwa elemen penting untuk diajarkan pada skill berbicara adalah pengucapan kosa kata dan pemilihan Language expression yang tepat, intonasi, tata bahasa dan kelancaran menyampaikan suatu ide. Sedangkan Rohaeti (2014:3) mengatakan bahwa metode demonstrasi sangat sesuai dalam memberikan ketrampilan proses kepada peserta didik dan dapat memberikan pengalaman belajar yang lebih konkret.

Tahap awal pelaksanaan pelatihan kepada peserta pelatihan, diberikan semacam set introcduction (perkenalan awal) dan motivasi untuk memberikan stimulus agar peserta termotivasi untuk mengikuti kegiatan belajar bahasa Inggris dari tahap awal sampai selesai dengan baik, lalu dilanjutkan dengan memberikan pertanyaan- pertanyaan sederhana kepada peserta untuk mengetahui kemampuan awal mereka tentang bahasa Inggris sehingga memudahkan tim pengabdi dan mahasiswa untuk masuk dalam pembuatan materi dan penyempaian materi yang tepat selama kegiatan berlangsung sehingga dalam pelaksanaan kegiatan dari awal sampai akhir dilakukan berbagai macam praktek percakapan sederhana dan juga bermain peran yang berhubungan dengan kepariwisataan dan juga bahasa Inggris sehari-hari.

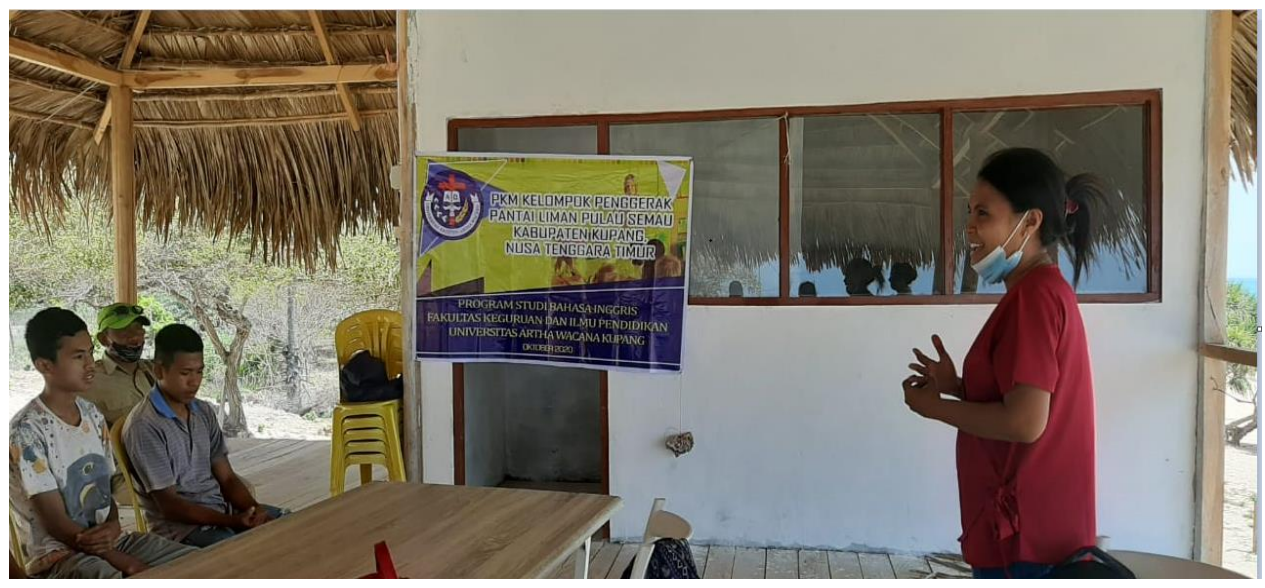

Gambar 2. Tahapan pelaksanaan melalui ceramah dan memberikan motivasi kepada peserta

\section{HASIL DAN PEMBAHASAN}

Pelaksanaan kegiatan pengabdian yang dilakukan oleh tim pengabdi bersama mahasiswa dilakukan dari tanggal 28 Agustus 2020 sampai dengan tanggal 28 Oktober 2020 dengan jumlah peserta yang mengikuti kegiatan adalah sebanyak 18 orang yang terdiri atas 6 orang dewasa yang bekerja sebagai resepsionis dan juga pegawai di home stay Liman serta 12 anak-anak usia sekolah dasar dan menengah yang biasa berjualan didekat kawasan pantai Liman dan kegiatan ini bertempat langsung dikawasan pantai dan home stay yang ada di pantai Liman. Pelatihan yang dilakukan selama kurang lebih 2 bulan ini diawali dengan pertanyaan sederhana seputar kesulitan yang dihadapi oleh peserta dalam berkomunikasi dalam bahasa Inggris dan juga bagaimana sikap yang baik dan tepat dalam memberikan pelayanan kepada tamu atau wisatawan yang datang berkunjung ke pantai Liman.

Dari jawaban yang diberikan diketahui bahwa hampir sebagian besar peserta mengalami kesulitan dalam berkomunikasi dengan bahasa Inggris karena mereka tidak pernah belajar bahasa Inggris secara intensif dan juga mereka tidak pernah melakukan praktek berkomunikasi dalam bahasa Inggris dengan siapapun. Selain itu, oleh karena faktor ketidak tahuan tentang bahasa Inggris yang memadai dan juga tidak pernah melakukan praktek berbicara dengan orang lain maka hal tersebut berdampak pada rasa takut dan merasa tidak percaya diri untuk berbicara dalam bahasa Inggris. Sedangkan kemampuan guiding dan juga sikap dalam memberikan pelayanan kepada tamu atau wisatawan yang datang berkunjung belum pernah mereka dilatih secara khusus 
tentang hal-hal terkait penatalayanan terhadap tamu atau wisatawan yang akan mereka layani baik tamu atau wisatawan dalam negeri ataupun luar negeri.

Kegiatan ini kemudian dilanjutkan dengan pemberian materi dasar awal yang sangat sederhana, dimulai dengan belajar tentang salam/sapaan (greeting) dalam bahasa Inggris, dan dilanjutkan dengan bagaimana memperkenalkan diri sendiri kepada orang lain (introduction), dan bagaimana menanyakan tentang identitas orang lain, cara berterimakasih (thanking) Hal ini dilakukan dengan metode ceramah dan juga demonstrasi secara singkat kepada peserta. Kemudian peserta diberikan kesempatan untuk berlatih secara mandiri bersama dengan pasangan terkait dengan materi yang baru diberikan dengan memberikan gambaran situasi seolah-olah mereka sementara berbicara dan melayani tamu atau wisatawan asing. Dari kegiatan yang dilakukan ini, peserta bisa melafalkan percakapan secara baik terkait bagaimana memberikan salam dan sapaan yang tepat, memperkenalkan diri sendiri, bertanya tentang identitas orang lain dan juga cara menyampaikan terimakasih.

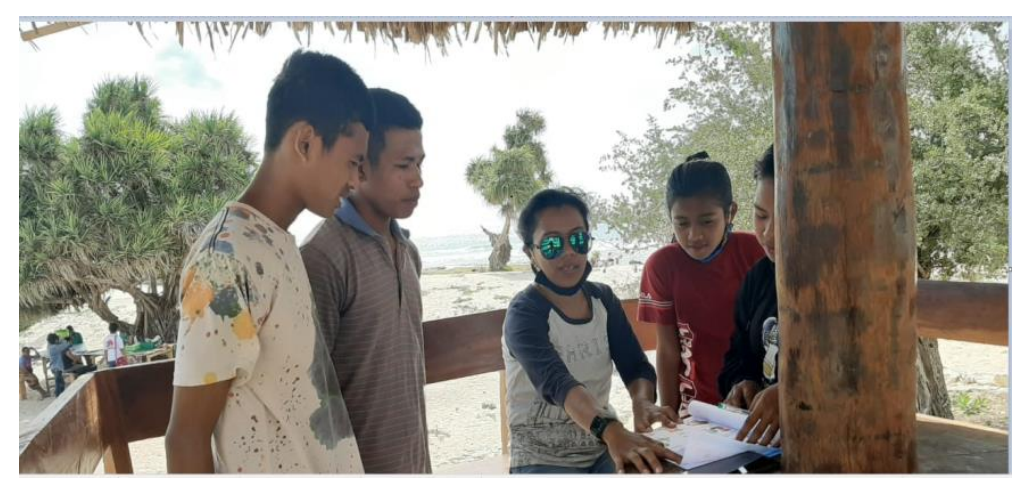

Gambar 3. Suasana kegiatan pelatihan bahasa Inggris dengan peserta anak-anak remaja

Materi pelatihan juga meliputi cara memberikan salam yang sesuai dengan kondisi waktu yang tepat dan juga sapaan yang benar, memperkenalkan diri, menawarkan bantuan yang semuanya dikemas juga dalam bentuk percakapan singkat dan pengetahuan tentang memberikan layanan dengan sikap yang penuh dengan keramahtamahan dan keberterimaan yang baik. Berikut ini adalah merupakan contoh percakapan praktis dan sederhana yang ada dalam materi.

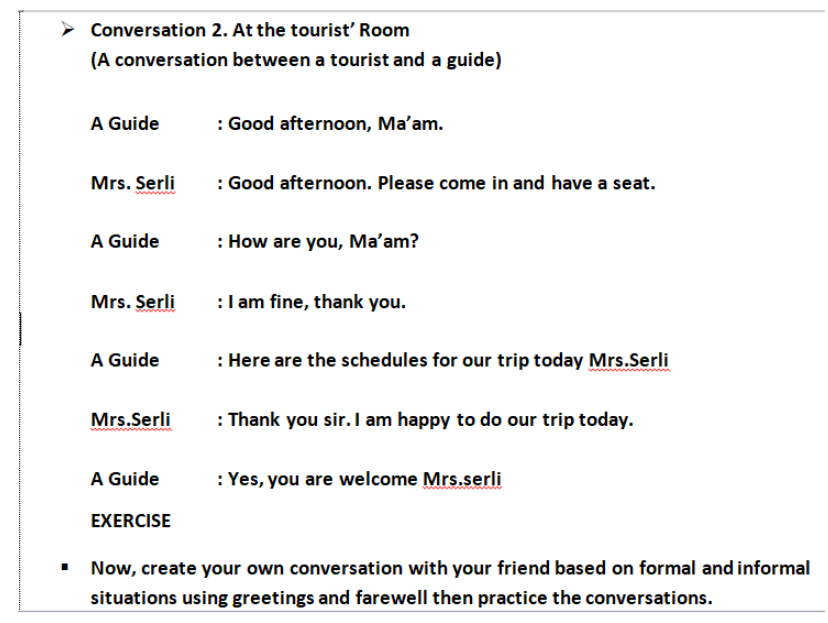




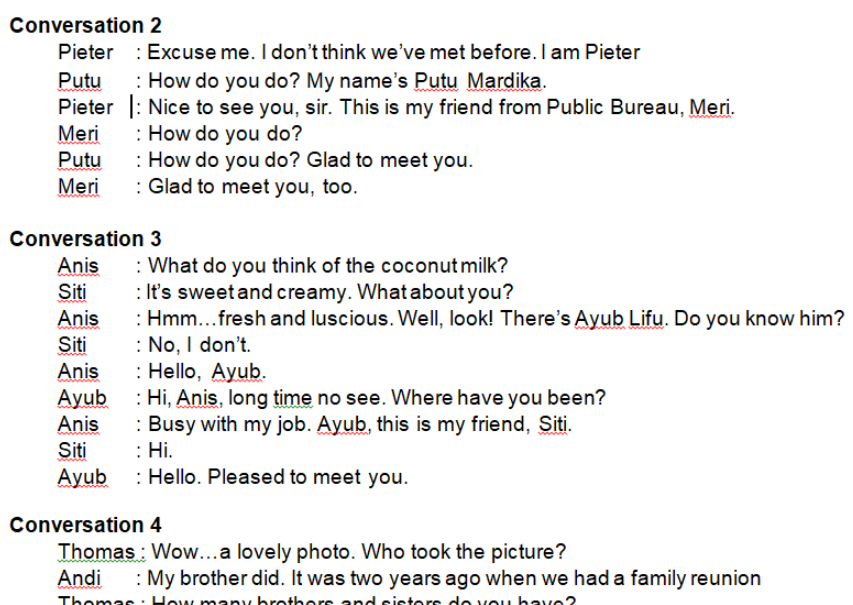

Gambar 4. Contoh beberapa materi yang dipakai selama kegiatan berlangsung

Kegiatan pengabdian kemudian dilanjutkan dengan diskusi terkait materi yang telah disampaikan sebelumnya lalu dilanjutkan dengan melakukan latihan percakapan singkat secara berpasangan dan juga bermain peran sesuai dengan situasi yang diberikan kepada peserta untuk dilakukan. Dari hasil pengamatan dilapangan, terlihat peserta sangat antusias dan senang dalam mempraktekkan percakapan singkat dalam bahasa Inggris serta keikutsertaan dalam bermain peran dan juga bentuk belajar lewat bermain. Peserta mulai berlatih berbicara dengan menggunakan intonasi dan pengucapan yang benar serta berlatih menghafalkan percakapan singkat dengan ekspresi yang benar dan apabila ada pelafalan kata yang masih belum tepat diucapkan dan digunakan maka tim pengabdi akan segera memberitahukan dan memperbaiki kesalahan yang dibuat. Peserta juga dibimbing tentang bagaimana memberikan pelayanan dan informasi kepada wiasatawan misalnya, menawarkan bantuan dengan cara dan komunikasi yang santun seperti, execuseme sir/mom, do you need any help? dan lain sebagainya. Materi yang diberikan kepada peserta dalam bentuk hardcopy.

Kegiatan dalam bentuk diskusi juga sangat menyenangkan bagi peserta hal ini terlihat ketika banyak peserta yang mengangkat tangan dan mengajukan pertanyaan berupa kosa kata yang sulit diucapkan oleh mereka, menanyakan arti yang tidak diketahui serta beberapa istilah kosa kata seperti makanan dan minuman lokal yang ada dalam bahasa lokal yang hanya dikenal oleh masyarakat atau penduduk yang ada di Nusa Tenggara Timur saja. Selain itu juga tentang istilah kebudayaan yang ada pada masyarakat setempat dan juga perbedaan kebudayaan yang berbeda yang perlu untuk mereka ketahui sehingga mereka bisa memakai etika berkomunikasi yang baik serta memahami dengan baik tentang lintas budaya yang ada. Ada juga beberapa peserta yang meminta untuk diberikan tips bagaimana agar mereka kelak bisa berbicara bahasa Inggris dengan lancar oleh karena ketidak percayaan diri dan keterbatasan pengetahuan mereka membuat mereka takut ketika harus berbicara dalam bahasa Inggris, sehingga tim pengabdi membantu lewat menberikan beberapa tips dan juga motivasi yang kuat kepada peserta untuk terus belajar dan berlatih dengan tekun serta membuang rasa takut atau malu untuk berbicara dalam bahsa Inggris meskipun sering melakukan kesalahan dalam pengucapan, pemilihan kata, maupun strukturnya karena dengan terus berlatih berbicara dalam bahasa Inggris maka kelak mereka akan mendapatkan hasil yang baik.

Secara garis besar dapat dikatakan bahwa para peserta sudah memiliki niat dan kemauan yang sangat besar dalam dirinya untuk belajar bahasaInggris. Hal ini terlihat dengan semangat dan juga presentasi kehadiran mereka yang cukup tinggi pada setiap pertemuan meskipun beberapa diantaranya ada yang sering hadir terlambat oleh karena masih membantu orang tua dikebun. Akan tetapi ketidak ketersediaanya lembaga kursus atau pelatihan bahasa Inggris membuat kesempatan belajar bagi mereka tidak ada dan juga tidak adanya teman ataupun sumber materi yang bisa menjadi bahan pegangan untuk mereka belajar secara mandiri maupun bersama sehingga hal ini menyebabkan mereka kesulitan dalam belajar bahasa Inggris. 


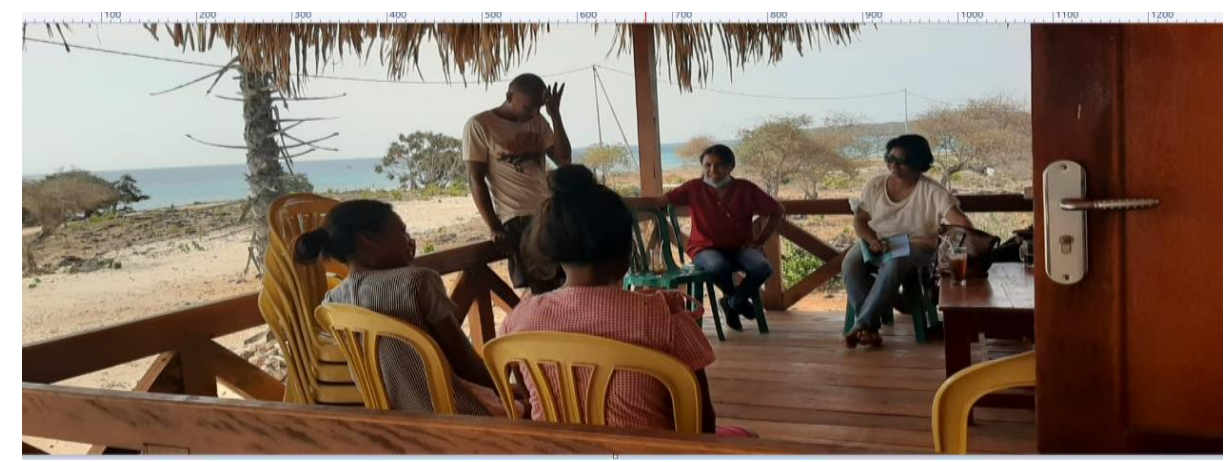

Gambar 5. Salah seorang peserta yang berprofesi sebagai pelayan di homestay yang diberi kesempatan untuk memberikan praktek greetings kepada teman-teman

Kegiatan ini berlangsung secara berkelanjutan selama kurang lebih 2 bulan dengan didampingi oleh 4 orang mahasiswa untuk ada bersama dengan semua peserta selama masa kegiatan berlangsung. Diakhir kegiatan dilakukan evaluasi untuk melihat peningkatan kemampuan berbahasa Inggris dan juga pemahaman pengetahuan tentang sikap dalam memberikan pelayanan jasa wisata kepada tamu atau wisatawan yang datang berkunjung ke pantai Liman ini.

Berdasarkan hasil evaluasi yang dilakukan diakhir kegiatan pengabdian ini terlihat bahwa kemampuan berkomunikasi dalam bahasa Inggris dari para peserta mengalami peningkatan dimana yang awalnya mereka begitu takut dan tidak percaya diri ketika diminta untuk berbicara dalam bahasa Inggris namun setelah mengikuti pelatihan bahasa Inggris yang diberikan sekarang mereka sudah tidak lagi takut dan malu untuk tampil kedepan dan berbicara dalam bahasa Inggris bahkan ketika diberikan pertanyaan dalam bahasa Inggris semua peserta memberikan jawaban secara serentak, selain itu ketika diminta untuk membuat percakapan sendiri dengan instruksi situasi yang diberikan mereka mampu menyelesaikan dan melakukannya dengan baik tanpa rasa takut. Demikian hal nya dengan cara mengucapkan kosa kata yang sulit dalam bahasa Inggris yang mana beberapa dari mereka telah sangat baik mengucapkan kata-kata yang ada dengan pengucapan dan intonasi yang tepat. Sedangkan dalam hal memberikan pelayanan jasa dan memberikan informasi kepada wisatawan mereka telah mengetahui hal-hal baik yang harus mereka lakukan dan hal-hal yang tidak baik untuk tidak mereka lakukan.

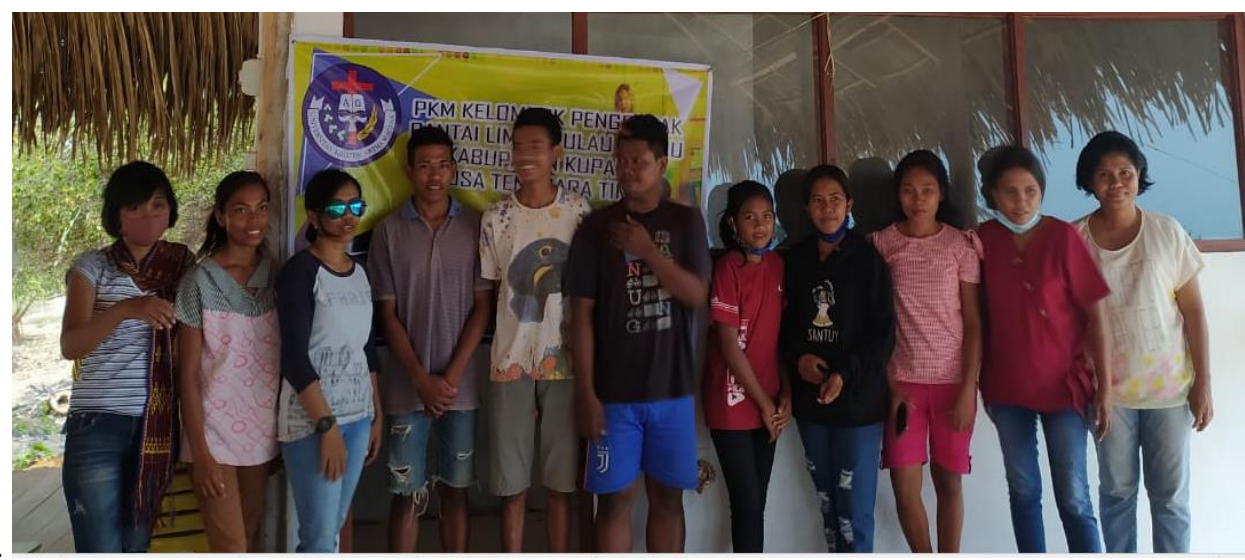

Gambar 6. Tim pengabdi dengan sebagian peserta kelompok penggerak pariwisata

\section{SIMPULAN}

Secara keseluruhan hasil dari kegiatan yang telah dilakukan di kawasan pantai Liman ini bagi para kelompok peggerak pariwisata berjalan dengan baik dan lancar. Hasil yang dicapai adalah hampir sebagian besar peserta yang mengikuti kegiatan ini mengalami peningkatan dalam berbahasa Inggris dimana para peserta sudah bisa berbicara dan memberikan respon dalam bahasa Inggris sederhana dan tidak lagi takut untuk berbicara dalam bahasa Inggris, dan bisa mengucapkan kata-kata dengan pengucapan dan intonasi yang benar terkait topik-topik dalam 
materi selama kegiatan berlangsung.

\section{SARAN}

Kegiatan pengabdian kepada masyarakat ini adalah untuk mewujudkan desa Liman sebagai desa Kawasan wisata berbasis Edugreen-tourism melalui kelompok penggerak pariwisata kawasan pantai Liman. Oleh karena itu, hendaknya kegiatan ini dapat berkelanjutan melalui pendampingan dan kegiatan yang sama agar pemahaman dan kemampuan dasar yang telah mereka peroleh dapat terus dipertahankan dan ditingkatkan. Para peserta yang merupakan kelompok penggerak wisata yang telah mengikuti kegiatan agar terus berlatih bahasa Inggris secara mandiri maupun dalam kelompok bersama teman dan kelompok pelaku usaha lainnya dengan materi yang diberikan untuk pengembangan desa Liman sebagai Desa Wista yang berbasis edugreen tourism.

\section{UCAPAN TERIMA KASIH}

Terima kasih kami sampaikan kepada Universitas Kristen Artha Wacana Kupang melalui LPM yang telah sepenuhnya membiayai seluruh rangkaian kegiatan PKM ini. Terima Kasih juga kami Sampaikan kepada Rektor Universitas Kristen Artha Wacana Kupang, Kepala LPM dan Dekan Fakultas Keguruan dan Ilmu Pendidikan yang telah mendukung kegiatan ini untuk dapat berjalan dengan baik. Ucapan terimaksih juga kami sampaikan kepada mitra dari kegiatan ini yaitu pemerintah desa dalam hal ini Kepala Desa Liman yang telah membantu mengarahkan, mendukung dan memberikan motivasi secara penuh pada kegiatan ini. Ucapan terimaksih juga bagi masyarakat yang ada di desa Liman khususnya peserta yang telah memberikan waktu dan dirinya untuk mengikuti kegiatan yang berlangsung.

\section{DAFTAR PUSTAKA}

Raharjana, Destha Titi. 2010. Membangun Pariwisata Bersama Rakyat: Kajian Partisipasi Lokal dalam Membangun Desa Wisata di Dieng Plateau.

Rohaeti, Salimi, Sugiyono. (2014). "Peningkatan Hasil Belajar Siswa dengan Menggunakan Metode Demonstrasi dalam Pembelajaran". Jurnal Pendidikan dan Pembelajaran, III (4), halaman $1-12$.

Richard, J. (2001). Curriculum Development in Language Teaching. New York: Cambridge University Press. 